\title{
Alternative Affective Assessment of Civic Learning in Distance Learning During the Covid Pandemic 19
}

\author{
Patmisari Patmisari ${ }^{1 *}$, Alil Rinenggo ${ }^{2}$, Wibowo Heru Prasetiyo ${ }^{3}$ \\ ${ }^{1,3}$ Universitas Muhammadiyah Surakarta, Indonesia \\ ${ }^{2}$ Universitas Darul Ulum Islamic Pusat Sudirman GUPPI, Semarang,, Indonesia \\ *Corresponding author.Email: patmisari@ums.ac.id
}

\begin{abstract}
The purpose of this paper is to provide an alternative assessment approach for teachers in civic learning so that it can be used as a reference for civic teachers to conduct the affective assessment. This research is included in the Library Research type of research. Data is obtained from various books, journals, scientific papers, and other documents that examine the distance learning assessment model. The results showed that five assessment approaches could assess students' attitudes: survey techniques, interviews, observation, self-assessment, and user data. The survey approach is most commonly used in various disciplines to show course satisfaction, perceived course usability, and intention-fulfilment. Interviews were used to reveal experiences during their learning, such as professional development, leader motivations, and barriers. Self repost with a Likert scale reflects students' perceptions of affective learning outcomes, such as learning experiences, perceived learning benefits, and civic learning satisfaction. Observation and self-assessment are used to reveal students' evaluations of learning experiences and distance learning benefits. Meanwhile, user data is used to measure the experience and emotional state of students.
\end{abstract}

Keywords: Affective Assessment, Online-Based Learning, Civic Learning.

\section{INTRODUCTION}

During the Covid-19 Pandemic, the education system has experienced a paradigm shift. Since the beginning, almost all learning in schools was carried out offline, but the government decided that education was carried out online during the Pandemic. This step was taken to stop the spread of Covid-19. After the Pandemic has been running for almost a year, the Indonesian Minister of Education encourages local governments to hold offline learning with health protocols and 50 per cent capacity [1]. This offline learning is an option for each area in the yellow and green zone with school residents and related parties [2]. Education has been carried out using blended learning, meaning that learning can be done online and offline according to the situation and condition of each area by paying attention to health protocols.

Learning that is carried out online certainly experiences several obstacles. Problems with quotas, networks, gadgets, and laptops are often complained of by students who take lessons. These constraints result in learning activities not running well and smoothly. The Ministry of Education and Culture has finally released internet quota assistance for online learning. The amount of the quota differs based on the school level [3]. The teacher must understand students' abilities and backgrounds so that obstacles can be appropriately overcome and smoothly during distance learning.
During the Pandemic period, citizenship education in Indonesia became a central point in the world of education because it was related to the compliance and attitude of citizens in overcoming Covid-19. Citizenship Education has a function to promote and form good citizens, especially in the context of the character and development of Indonesian civilization based on the values of Pancasila [4]. Citizenship education is usually promoted as an investment in the future of democracy [5]. Civic education aims to create citizens with civic competence, namely the knowledge, skills, and character of citizenship [6]. According to Ngozwana, citizenship education encourages citizens to participate in government and promotes knowledgeable and responsible citizens, enhancing democracy [7]. Based on the explanations of several of these figures, the significant emphasis of the goals and benefits of citizenship education is to focus more on the values, character, or behaviour of citizenship. It is hoped that civic education can contribute and benefit distance learning by strengthening the affective aspect.

On the one hand, distance learning has a positive impact with ease of access, it is not limited by time and space, but on the other hand, it also has a negative effect. For example, some students do not pay attention, follow the lesson, seem like a formality, and efficiently plagiarize from the internet without mentioning the source. Cahyono explains that distance learning or online learning is less 
effective because not all students and schools have supporting facilities for the distance learning process [8]. The Knight Foundation explains that digital engagement learning opportunities develop students' capacities in creating and sharing media and opinions (perspectives). Second, there is a growing concern about spreading inaccurate information on the internet [9]. The tactical strategy used by PPKn teachers in making it easier for students to carry out distance learning is with various learning media that can be accessed by all students, such as WhatsApp or google classroom [10].

Learning assessment when learning online is critical to measure and evaluate the progress of student learning outcomes, attitudes, and skills, in line with Fenton's opinion that the use of assessment as part of the learning process reflects the understanding and progress of each individual [11]. In practice, affective assessment gets less special attention from the teachers. Sometimes, the development of student attitudes becomes uncontrollable, for example, irritability, disrespect for teachers, harsh words, lack of discipline, and responsibility. The results show that the lack of character education is caused by teachers who only pay attention to the cognitive aspects and ignore students' affective, psychomotor, and spiritual elements [12]. A study shows that, in general, the civic engagement of Palangka Raya University students in terms of science is in the medium category. In terms of attitude, most students fall into the high class. Judging from their behaviour, most of them fall into the low category. The results are not linear between Indonesian citizenship knowledge, attitudes, and behaviour [13].

The constraint that teachers or teachers often exerience is doing affective assessments during distance learning. Dinatha states that affective examination assesses character and behaviour, such as attitudes, values and morals, self-concept, and interests [14]. These affective aspects cannot be observed, and it isn't easy to assess during distance learning. In line with Gusti's findings that after online learning makes educators unable to observe students directly, this indirectly leads to affective assessments that include behavioural traits such as feelings, interests, attitudes, emotions, or values at the time [15]. Follow online learning. Effective and meaningful learning can be achieved if students have positive cognitive and emotional states during education [16].

Affective assessment must have the right measuring tool because it is based on observations of the attitudes and behaviour of each student. The results of the affective evaluation are used as a guide for teachers to provide direction or guidance to students. The development of attitudes is following the norms in society. Teachers can develop measuring tools for affective assessment with taxonomic levels of affective domains. Krathwohl proposed five taxonomic groups of the affective domain: accept, respond to, appreciate, value conceptualization, and value characterization [17].
Research from Wijianto explains that Citizenship Education Lecturers in higher education find it challenging to develop active verbs in the affective and skills assessment stages [18].

The writing of this article seeks to provide an alternative affective assessment using several approaches that can be used as an appropriate measuring tool for distance learning. The author is interested in describing this theme because it follows the situation and learning conditions during the Pandemic. Affective assessment is critical to be carried out by teachers so that student attitudes can be controlled and well-directed. With this paper, it is hoped that it can provide understanding and concrete steps for teachers to use appropriate measuring tools to assess student attitudes during distance learning.

Collecting data using literature study techniques with a qualitative approach. Data was collected through journal articles and books relevant to civic education, affective assessment, and distance learning (online) during the Pandemic. The writer downloads journal articles from the official website and reads books that match the writing topic in the first stage. In the second stage, the writer reads comprehensively by finding the main ideas. After the core idea is located in the third stage, the appropriate data is selected to describe the results and discussions related to writing. In addition to the literature study, the authors also observed symptoms related to distance learning during the Pandemic to strengthen the research findings.

\section{THEORETICAL REVIEW}

\subsection{Basic Concepts of Assessment and Evaluation}

Cronbach explains that an assessment is a procedure for concluding: 'One validates, not a test, but an interpretation of the data that emerges from a particular procedure' [19]. Assessment in education is a collection of information about student learning in many ways for two primary purposes: to provide feedback into the learning process and for reporting to various audiences and measure how much of a certain quality is [20].

Assessment is one of the various procedures used to obtain information about student performance. First, formative assessment, referred to as 'assessment for learning,' occurs before or during teaching and is designed to provide timely feedback and specific guidance. It is often not graded or graded because it is intended to inform the learning and teaching process. Second, a summative assessment is designed to provide all interested parties with a clear, meaningful, and helpful summary or calculation. The assessment is about how well a student has met the teacher's goals. Tests are carried out to assign letter or number grades to assess learning and summarize how well students perform over time and on various tasks [21].

Rönnebeck et al. stated that assessment is simply the production and interpretation of evidence of achievement. If 
this evidence is used to guide the next step in progress, it is for [formative] learning; if it is used to conclude, assess, make decisions about progress so far, it is [summative] understanding" [22].

There are several assessment types: formative and summative; formal and informal; external and internal; authentic and inauthentic; oral and written. In addition, the assessment can be based on criteria, refers to norms and suggestions, focuses on differentiation and discrimination, and is carried out by experts, peers, and oneself [23].

Griffin \& Care explains that the BEAR Assessment system is based on four principles, namely [24]:

Principle 1: Assessment should be based on the developmental perspective of student learning, seen from the progress variable that describes the development of students and how we think about their possible changes in response to items.

Principle 2: There must be a match between what is taught and what is assessed.

Principle 3: Teachers must be systems managers, with the tools to use them efficiently and effectively, viewed from the results space or the set of categories of student responses that make sense to the teacher.

Principle 4: There is quality evidence regarding the study's reliability and validity and proof of fairness.

The challenge of educational assessment is an assessment that advances learning and teaching goals to provide helpful information about students' progress towards learning objectives in a reliable and undifferentiated way [25]. Teachers have to carry out assessment literacy and be able to provide understandable and valuable feedback. Still, students also need to be assessment literate to take advantage of feedback and exploit information gathered through various assessment activities [26].

The meaning of assessment is different from the meaning of evaluation. Sudjana states that evaluation is a process of assigning or determining value to a particular object in the form of an interpretation that ends with a judgment based on specific criteria [27]. The purpose of the evaluation is to obtain accurate and objective information about a program. The data can be in the form of program implementation processes, impacts or results achieved, efficiency, and utilization of program-focused evaluation results. That is for decision-making related to the program's continuation, improvement or termination and can be used to benefit further program preparation [28].

The most widely used evaluation model in education, especially about more traditional methods. This model aims to find answers to different questions, namely: Level 1: Reaction, which seeks to understand the balance that students make from educational activities; Level 2: Learning, targeting the assessment of student progress in terms of knowledge construction and competency development, namely in terms of assessment products; Level 3: Behavior/Transfer, to identify the extent to which learning is transferred to the work context, and Level 4: Outcome, which relates to the impact of training, taking into account econometric criteria [29]. Waseso details the difference between assessment and evaluation as follows [30].

1) According to Frith and Macintosh, assessment relates to how children benefit from a teaching process. Evaluation is related to the effectiveness of the learning process.

2) Evaluation is more abstract and broad than assessment, but according to Linn and Gronlund, a more general assessment of various information acquisition procedures can be used.

3) According to the Terms, the assessment takes a long time because it involves an ongoing process, while the evaluation is carried out periodically.

4) Assessment is more focused on finding data about students. At the same time, evaluation can be broader than that (achievement of learning objectives, level of teacher mastery, classroom teaching, the effectiveness of methods/media, and others).

\subsection{Civic Learning Competences}

Civic learning or civic education learning aims to form active participation in social, political, and community life, supported through democratic experiences and determined by a pedagogical approach [31]. Experience and involvement in democratic decision-making processes are appropriate for introducing democracy and democratic values and attitudes. Every citizen must participate in living the democracy that is part of their daily life. Understanding such as democracy will be based on emancipatory values such as tolerance, solidarity, readiness for dialogue and cooperation, justice, compassion for others [32]

Murray Print argues that schools are the primary agents in providing formal citizenship education and, more importantly, informal opportunities to learn to become active and democratic citizens [33]. Dürr argued that education still plays an essential role in human life [34]. That is the reason why teacher education is so important. Active and democratic citizens, competent educators are needed who will provide adequate education for civic democracy. Salema argues that educators play an essential role in supporting the learning experiences of young people and adult learners [34]. The research results conducted by Geboers, Geijsel, Admiraal, Dam show that teachers' pedagogical abilities play a significant role in creating a democratic atmosphere in the classroom, for example, by creating a classroom atmosphere with discussion and dialogue [35]. In the process of a debate and dialogue, it will give rise to respect for other people when discussing or having conversations. Creating a pedagogical climate in the classroom is the most studied and quite effective type of civic education. 
Citizenship education teaches citizens to be active and democratic. Students who have received civic education in separate, integrated, and cross-curricular subjects are expected to apply knowledge, skills, values, and attitudes to become active and democratic citizens throughout their lives. Citizenship education curriculum has an essential role in realizing democratic citizenship.

The term civic learning often refers to learning practices in civic education, such as discussing current issues and learning about problems that occur in society [36]. In general, experts have found that citizenship learning, such as discussion of current events and controversial issues, service issues, and governance issues, positively impacts citizenship knowledge, civic commitment, and politics [36][37]. Campbell found that students in the classroom were freely displayed with a high understanding of citizenship when discussing political issues [38]. Youniss and Yates argue that civic learning can develop a youth citizenship identity driven by three factors: citizenship agents, social linkages, and political and moral understanding [39]. Civic learning allows students to respond to social problems through group projects by developing relevant skills [39]. It turns out that discussions are often more interesting than other classroom activities, making students more concerned about discussing citizenship issues [38].

\subsection{Distance Learning}

Distance learning is learning from home where students and teachers are physically far apart [40]. Research shows that access to technology, resources, and quiet spaces to study is essential [41]. The improvement of the distance learning system must be through the introduction of learning technology. The learning is competency-oriented as a complex of various forms of presentation of theoretical material and the organization of practical exercises. Such education should activate students and lead to their information and professional competence in the educational process [42]

Distance Learning is changing primarily due to the availability of new technologies (e.g., whiteboards, lecture broadcasting, DVD availability, internet). Furthermore, the changes can be seen in innovative pedagogy (the introduction of virtual learning and creating online communities). The opening and use of new technologies gave e-learning, which significantly impacted the learning environment [43].

The main advantages of distance learning can be described as follows. First, Availability. Distance learning can get knowledge from anywhere in the world. Second, flexibility. In the distance learning process, most of the material that students learn independently. So, they are free to choose the time for class. Third, relatively save money and time. Fourth, one is not dependent on transportation. Apart from saving money, it allows saving a lot of free time. Fifth, improve technical skills. Students learn how to navigate different learning management systems and programs. However, there are some downsides to distance learning as well. First, not all study programs can be studied remotely. Second, limit personal communication. Third, facing unforeseen circumstances that will interfere, such as power failure and the internet, can be cut off during important online seminars, technology addiction, lack of control, and constant monitoring by teachers [44].

Distance learning has great potential to set high standards for valuable learning experiences in virtual environments. Experiments have revealed that students persist in online learning but are concerned about the quality of interactions with teachers and the university's undeveloped technological infrastructure [45]. The ODL (Online Distance Learning) model can create an effective relationship between special learning needs and technology. Both lecturers and students enjoy the benefits of saving resources (classroom, time, electricity, transportation, etc.) and not depending on time and place [46].

In distance learning, agencies need to: (1) introduce e-Learning technology to students as early as possible, (2) provide e-Learning Applications with excellent usability and practical instructional design, (3) provide clear instructions (e.g., manuals rules) for students and instructors, and (4) providing materials or financial support needed for students to enable them to participate in online learning sessions [47].

\subsection{Alternative Affective Assessment Approaches Civic Learning}

Civic disposition is an intermediary between the development of the dimensions of civic education knowledge and civic skills. Civic disposition refers to characters, attitudes, or daily habits of life that reflect the goodness of citizens, for example, religion, honesty, tolerance, hard work, creativity, independence, democracy, curiosity, Care for the environment, Care for society, hospitality, responsibility. The answer, love the country, love peace, and national spirit. The characters that exist in a country describe the uniqueness of the country. The character of the Indonesian nation is imbued with the values of Pancasila. These character values consist of religious importance, honesty, tolerance, discipline, hard work, creativity, independence, democracy, curiosity, national spirit, love for the country, respect for achievement, friendship/communication, peace of mind, love to read, care for the environment, social care and responsibility [48].

Citizenship education emphasizes the dimensions of character, traits, affective attitudes, and other potentials [49]. In the learning process, an assessment is needed to measure the success or learning objectives. Affective assessment or attitude assessment becomes one of the assessments in civic disposition.

Affective assessment refers to the perception of learning, especially at this time, distance learning in the pandemic era. Aspects in the affective evaluation include 1) student satisfaction in learning or evaluation in learning; 2) perceptions of learners' learning experiences in learning; 3) the learning benefits felt by students [50]. Student satisfaction is measured by the realization of learning objectives [51]. Students will feel a higher level of satisfaction from peer interactions such as support from friends and sharing with other students. In addition, satisfaction is measured from learning, learning activities, and assignments.

Perceptions of online learning experiences explore how emotional learners feel, for example feeling bored or enjoying learning [52]. In addition, the learning experience can be shown by several types of emotional tendencies, namely sadness, joy, anger, disappointment, surprise, pride, 
falling in love, and fear. [53]. Several studies reveal students' perceptions regarding learning design, learning content, presence of teaching, ease of use and utility, usefulness of learning, complementarity, ease or difficulty of controlling behaviour, and user preferences [54]-[56]. Students experience various challenges and obstacles in online learning, such as workload, lack of in-depth conversations in discussion forums, insufficient knowledge of topics, previous bad experiences with subjects, and inadequate time to learn [57], [58].

Perceptions of the benefits of distance learning see how motivated students to take part in distance learning, such as knowledge of arguments, increased work skills, future career development, and personal interests [57]. Another benefit that is felt when learning online is the effectiveness of learning in general [54], increased knowledge [59], learning skills [60], a sense of progress [54], and a sense of trust [61].

Instruments such as surveys, interviews, observations, self-assessments, and user data are used as evaluation tools to explore various aspects of distance learning civic learning when observing affective or behavioural assessments. To assess behavioural outcomes; user data is often used to reveal different kinds of objective learning behaviours [62]

\section{1) Survey.}

The survey is used to measure student satisfaction, perceived benefits, and intention-fulfilment in online learning [58], [63].

2) Interview.

Assessment through interviews reveals the interviewee's evaluation of their learning [58], [63]. Meanwhile, more in-depth interviews such as obstacles can conduct semi-structured interviews with open questions to several students [64].

\section{3) Observation.}

Observation is also used to evaluate students regarding the experiences and benefits of learning in distance learning [65].

\section{4) Self-assessment.}

Assessing the experience and benefits of learning can use self-assessment. The Likert scale is commonly used in self-assessment questionnaires to reflect students' perceptions of affective learning outcomes such as learning experiences, perceived benefits, and satisfaction in the learning process [55], [56].

\section{5) User Data.}

User data is used to identify the emotions learners experience and emotional states [66]. Concerning the assessment of behavioral outcomes, user data is often adopted to reveal various types of objective learning behavior, record the trajectories of students' learning processes, and capture moments of student activity during MOOC learning. Through user data, it can provide an overview of how students behave while learning, such as the duration of listening to teaching videos, commenting in discussion forums, and completing and submitting assignment assessments. This data will provide quantitative information to teachers regarding the extent to which students are involved in learning.

Extracting user data can provide insight into how students behave while studying, such as the time/duration of watching lecture videos, the number of posts/replies/comments on discussion forums, and the completion and submission of assessment assignments. This data can provide quantitative information to curriculum teachers about the course and reveal how learners are involved in course learning. (Bonafini, 2018). Apart from that, user data can also help explore more advanced and complex learning processes. For example, students' various access points to learning resources and different independent learning strategies used by students [67] and problem-solving patterns used by students [68].

\section{CONCLUSION}

The citizenship learning process is learning whose output is integrated between cognitive, affective, and skills aspects. These three aspects need to be assessed to determine how far the benefits are obtained by students and provide feedback that needs to be done by the teacher so that students can be well directed and controlled.

Affective assessment in Citizenship Learning in the Era of the Covid-19 Pandemic is very important because learning takes place in blended or distance learning. Several relevant approaches for the affective evaluation are survey, interview, observation, self-assessment, and user data to determine the student's learning experience, students' learning motivation, learning satisfaction, the benefits of distance learning, and students' emotions. The implication is that teachers can apply appropriate strategies to provide treatment, guidance, methods, learning approaches that can improve activities or learning processes as expected.

\section{ACKNOWLEDGMENTS}

The author would like to thank those who have contributed to the writing of this article. We do not forget to thank the Universitas Muhammadiyah Surakarta and Universitas Darul Ulum Islamic Centre Sudirman GUPII who have supported this writing activity.

\section{REFERENCES}

[1] C. Indonesia, "Khawatir learning loss, Nadiem dorong Pemda buka sekolah.," 2021. https://www.cnnindonesia.com/nasional/2021011317 0344-20-593273/khawatir-learning-loss-nadiemdorong-pemda-buka-sekolah.

[2] Kemdikbud, "Protokol kesehatan ketat untuk sekolah tatap muka di zona hijau dan kuning.," 2020. https://www.kemdikbud.go.id/main/blog/2020/08/pro tokol-kesehatan-ketat-untuk-sekolah-tetap-muka-dizona-hijau-dan-kuning. 
[3] C. Indonesia, "Pertama dalam sejarah sekolah tutup beralih ke online.," 2020. https://www.cnbcindonesia.com/tech/202012311756 05-37-212819/2020-pertama-dalam-sejarah-sekolahtutup-beralih-ke-online.

[4] B. Sumardjoko and M. Musyiam, "Model of civic education learning based on the local wisdom for revitalizing values of Pancasila," Cakrawala Pendidik., no. 2, 2018.

[5] K. Heggart, J. Arvanitakis, and I. Matthews, "Civics and citizenship education: What have we learned and what does it mean for the future of Australian democracy?," Educ. Citizsh. Soc. Justice, vol. 14, no. 2, pp. 101-117, 2019, doi: $10.1177 / 1746197918763459$.

[6] M. Y. Setiani and A. M. MacKinnon, "A community of inquiry-based framework for civic education at Universitas Terbuka, Indonesia.," Distance Educ., vol. 36, no. 3, pp. 351-363, 2015.

[7] N. A. Ngozwana, "Civic education in Lesotho: implications for teaching of democratic citizenship.," Int. J. Lifelong Educ., vol. 36, no. 5, pp. 526-540, 2017, doi: 10.1080/02601370.2017.1304460.

[8] Cahyono, "Penilaian pembelajaran Pendidikan Pancasila dan Kewarganegaraan (PPKn) dalam menumbuhkan sikap tanggung jawab pada peserta didik di masa Pandemi.," 2020.

[9] B. Bowyer and J. Kahne, "The digital dimensions of civic education: assessing the effects of learning opportunities.," J. Appl. Dev. Psychol., no. 69, 2020, doi: 10.1016/j.appdev.2020.101162.

[10] Mariyani and A. Alfansyur, "Strategi Guru PPKn dalam pelaksanaan pembelajaran jarak jauh selama masa Pandemi Covid-19 di Pali, Sumatera Selatan.," J. PINUS J. Penelit. Inov. Pembelajaran, vol. 6, no. 2, pp. 1-15, 2021.

[11] Wijianto, Winarno, and M. Al Rashid, "Innovation of Pancasila education assessment and citizenship school.," 2017.

[12] A. Prihastanto, S. Samsudi, and M. Masrukhi, "The development of holistic model of character education management for Senior High Schools In Pemalang Regency.," J. Educ. Dev., vol. 4, no. 1, pp. 73-82, 2016.

[13] E. Karliani, S. Kartadinata, and U. S. Winataputra, "Indonesian civic engagement among college students.," J. Hum. Behav. Soc. Environ., pp. 1-19, 2019, doi: 10.1080/10911359.2019.1571980.

[14] D. Dinatha, N.,M., "Pemanfaatan media sosial Facebook untuk menilai sikap ilmiah (afektif) mahasiswa.," J. Educ. Technol., vol. 1, no. 3, pp. 211$217,2017$.
[15] A. Gusti, Y. Afriansari, and A. Walid, "Penilaian afektif pembelajaran daring IPA terpadu dengan menggunakan media Whatsapp," Diffr. J. Phys. Educ. Appl. Physics, vol. 2, no. 2, pp. 65-73, 2020.

[16] L. Wang, G. Hu, and T. Zhou, "Semantic analysis of learners' emotional tendencies on online MOOC education," Sustain., vol. 10, no. 6, 2018, doi: https://doi.org/10.3390/su10061921.

[17] B. B. Krathwohl, D.R, Bloom B.S. and Masia, Taxonomy of educational objectives: the classification of educational goal. Handbook II, Affective domain. New York: David McKay Co, Inc., 1964.

[18] Wijianto and R. Triastuti, "Improvement model of lecturer ability in preparation of assessment instruments civic education in Higher Education.," in Proceedings of the Borneo International Conference on Education and Social Sciences (BICESS 2018), 2018, pp. 575-579, doi: 10.5220/000902410575.

[19] D. Wiliam, "Assessment and learning: some reflections," Assess. Educ. Princ. Policy Pract., vol. 24, no. 3, pp. 394-403, 2017, doi: 10.1080/0969594x.2017.1318108.

[20] J. J. Smith, C. W., \& Cumming, Educational assessment in the 21st century connecting theory and practice. New York: Springer, 2009.

[21] S. Scott, Assessment in education implications for leadership. London: Springer, 2016.

[22] J. Dolin and R. Evans, Transforming assessment through an interplay between practice, research and policy. Switzerland: Springer, 2018.

[23] R. Berry and B. Adamson, Assessment reform in education policy and practice. New York: Springer, 2011.

[24] P. Griffin and E. Care, Assessment and teaching of 21st century skills methods and approach. London: Springer, 2015.

[25] H. Schoenfeld, A., "On learning and assessment," Assess. Educ. Princ. Policy Pract., vol. 24, no. 3, pp. 369-378, 2017, doi: 10.1080/0969594X.2017.1336986.

[26] W. Smith, C., Designing assessment for quality learning. London: Springer, 2014.

[27] N. Sudjana, Penilaian hasil proses belajar mengajar. Bandung: PT Remaja Rosdakarya, 2009.

[28] F. Ahmad, I., “Asesmen alternatif dalam pembelajaran jarak jauh pada masa darurat penyebaran Corona Virus Disease (Covid-19) di Indonesia," J. Pedagog., vol. 7, no. 1, pp. 197-222, 2020. 
[29] Balula \& Moreira., Evaluation of online higher education learning, interaction and technology. London: Springer, 2014.

[30] I. Waseso, "Modul 1 hakikat evaluasi dan asesmen," 2018. [Online]. Available: repository.ut.ac.id.

[31] J. Menthe, Education for Democratic Citizenship: Values vs Process. In Schools, curriculum and civic education for building democratic citizens. Brill Sense., 2012.

[32] G. Himmelmann, "Competences for teaching, learning and living democratic citizenship," in In Civic education and competences for engaging citizens in democracies, Brill Sense., 2013, pp. 1-7.

[33] F. Reichert, "Who is the engaged citizen? Correlates of secondary school students' concepts of good citizenship," Educ. Res. Eval., vol. 22, no. 5-6, pp. 305-332, 2016.

[34] K. Mrnjaus, "Teacher competences for education for democratic citizenship: Training and Classification Challenges," in In Schools, Curriculum and Civic Education for Building Democratic Citizens, Brill Sense., 2012, pp. 79-97.

[35] G. Geboers, E., Geijsel, F., Admiraal, W., \& Ten Dam, "Review of the effects of citizenship education," Educ. Res. Rev., vol. 9, pp. 158-173, 2013.

[36] J. Gould, K. . Jamieson, P. Levine, T. McConnell, and D. . Smith, "Guardian of democracy: The civic mission of schools.," 2011. [Online]. Available: https://www.civxnow.org/sites/default/files/resources /2011 Guard\%0Aian of Democracy.pdf.

[37] D. E. Campbell, "What social scientists have learned about civic education: A review of the literature," Peabody J. Educ., vol. 94, no. 1, pp. 32-47, 2019.

[38] J. Hoskins, B., D'hombres, B., \& Campbell, "Does formal education have an impact on active citizenship behaviour?," Eur. Educ. Res. J., vol. 7, no. 3, pp. 382402, 2008.

[39] J. Yates, M., \& Youniss, Roots of civic identity: International perspectives on community service and activism in youth. Cambridge University Press, 1999.

[40] M. Sadeghi, "A shift from classroom to distance learning: advantages and limitations," Int. J. Res. English Educ., vol. 4, no. 3, pp. 80-88, 2019.

[41] P. Mittelmeier, J., Rienties, B., Rogaten, J., Gunter, A., \& Raghuram, "Internationalization at a distance and at home: academic and social adjustment in a South African distance learning context," Int. J. Intercult. Relations, no. 72, pp. 1-12, 2019, doi: 10.1016/j.ijintrel.2019.06.001.
[42] L. G. Bobkova, E. Y., Korobejnikova, E. V., Nelyubina, E. G., Birina, O. V., \& Safina, "The conceptual aspects of the innovative format of the distance learning system within modern conditions of the higher education system informatization," Mediterr. J. Soc. Sci., vol. 6, no. 5, p. 131, 2015.

[43] A. C. Balfour, R. J., Van der Walt, J. L., Spamer, E. J., \& Tshivhase, "Blended learning, and open and distance learning: implications for best practice in higher education: leading article," Progressio, vol. 37, no. 1, pp. 1-18, 2015.

[44] D. K. Mirkholikovna, "Advantages and disadvantages of distance learning," Наука и образование сегодня, vol. 7 , no. $54,2020$.

[45] A. Leontyeva, I., "Modern distance learning technologies in Higher Education: introduction problems.," EURASIA J. Math. Sci. Technol. Educ., vol. 14, no. 10, 2018, doi: https://doi.org/10.29333/ejmste/92284.

[46] Y. Ghilay, "ODL: Online distance learning of quantitative courses in Higher Education," $A d v$. Soc. Sci. Res. J., vol. 4, no. 18, 2017, doi: 10.14738/assrj.418.3698.

[47] R. R. Hasani, L. M., Adnan, H. R., Sensuse, D. I., \& Suryono, "Factors Affecting Student's Perceived Readiness on Abrupt Distance Learning Adoption: Indonesian Higher-Education Perspectives," in In 2020 3rd International Conference on Computer and Informatics Engineering (IC2IE), 2020, pp. 2886292.

[48] T. M. of N. Education, "Guidelines for the Implementation of Character Education: Center for Curriculum Research and Development Agency Republic of Indonesia," 2010.

[49] N. Suryanto, A., Widodo, \& Dan, "The development of learning model based on controversial issues to strengthen the character of Civics disposition," Cakrawala Pendidik., vol. 37, no. 2, pp. 250-259, 2018, doi: 10.21831/cp.v37i2.15962.

[50] L. S. Post, P. Guo, N. Saab, and W. Admiraal, "Effects of remote labs on cognitive, behavioral, and affective learning outcomes in higher education," Comput. Educ., vol. 140, no. May, 2019, doi: 10.1016/j.compedu.2019.103596.

[51] M. de Lima and M. Zorrilla, "Social networks and the building of learning communities: An experimental study of a social MOOC," Int. Rev. Res. Open Distance Learn., vol. 18, no. 1, pp. 40-64, 2017, doi: 10.19173/irrodl.v18i1.2630.

[52] E. E. Buhr, L. M. Daniels, and L. D. Goegan, "Cognitive appraisals mediate relationships between two basic psychological needs and emotions in a 
massive open online course," Comput. Human Behav., vol. 96, no. February, pp. 85-94, 2019, doi: 10.1016/j.chb.2019.02.009.

[53] B. Li, X. Wang, and S. C. Tan, "What makes MOOC users persist in completing MOOCs? A perspective from network externalities and human factors," Comput. Human Behav., vol. 85, pp. 385-395, 2018, doi: 10.1016/j.chb.2018.04.028.

[54] E. Jung, D. Kim, M. Yoon, S. Park, and B. Oakley, "The influence of instructional design on learner control, sense of achievement, and perceived effectiveness in a supersize MOOC course," Comput. Educ., vol. 128, pp. 377-388, 2019, doi: 10.1016/j.compedu.2018.10.001.

[55] Y. Jung and J. Lee, "Learning Engagement and Persistence in Massive Open Online Courses (MOOCS)," Comput. Educ., vol. 122, pp. 9-22, 2018, doi: 10.1016/j.compedu.2018.02.013.

[56] H. H. Yang and C. H. Su, "Learner behaviour in a MOOC practice-oriented course: In empirical study integrating TAM and TPB," Int. Rev. Res. Open Distance Learn., vol. 18, no. 5, pp. 35-63, 2017, doi: 10.19173/irrodl.v18i5.2991.

[57] H. B. Shapiro, C. H. Lee, N. E. Wyman Roth, K. Li, M. Çetinkaya-Rundel, and D. A. Canelas, "Understanding the massive open online course (MOOC) student experience: An examination of attitudes, motivations, and barriers," Comput. Educ., vol. 110, pp. 35-50, 2017, doi: 10.1016/j.compedu.2017.03.003.

[58] S. L. Watson, W. R. Watson, J. H. Yu, H. Alamri, and C. Mueller, "Learner profiles of attitudinal learning in a MOOC: An explanatory sequential mixed methods study," Comput. Educ., vol. 114, pp. 274-285, 2017, doi: 10.1016/j.compedu.2017.07.005.

[59] A. B. Singh and A. I. Mørch, "An analysis of participants' experiences from the first international MOOC offered at the University of Oslo," Nord. J. Digit. Lit., vol. 13, no. 1, pp. 40-64, 2018, doi: 10.18261/ISSN.1891-943X-2018-01-04.

[60] B. C. Padilla Rodriguez and A. Armellini, "Developing Self-Efficacy through a Massive Open Online Course on Study Skills," Open Prax., vol. 9, no. 3 , p. 335 , 2017, doi: 10.5944/openpraxis.9.3.659.

[61] O. Praxis, “Open Praxis_Trad,” vol. 10, no. 2, 2018.

[62] X. Wei, N. Saab, and W. Admiraal, "Assessment of cognitive, behavioral, and affective learning outcomes in massive open online courses: A systematic literature review," Comput. Educ., vol. 163, no. March 2020, p. 104097, 2021, doi: 10.1016/j.compedu.2020.104097.
[63] L. Hudson et al., "Supporting urban change: Using a MOOC to facilitate attitudinal learning and participation in smart cities," Comput. Educ., vol. 129, pp. 2019, 37-47, doi: 10.1016/j.compedu.2018.10.012.

[64] M. E. Krasny et al., "Small groups in a social learning mooc (Slmooc): Strategies for fostering learning and knowledge creation," Online Learn. J., vol. 22, no. 2, pp. 119-140, 2018, doi: 10.24059/olj.v22i2.1339.

[65] J. Loizzo, P. A. Ertmer, W. R. Watson, and S. L. Watson, "Adult MOOC learners as self-directed: Perceptions of motivation, success, and completion," Online Learn. J., vol. 21, no. 2, 2017, doi: 10.24059/olj.v21i2.889.

[66] L. Wang, G. Hu, and T. Zhou, "Semantic analysis of learners' emotional tendencies on online MOOC education," Sustain., vol. 10, no. 6, 2018, doi: $10.3390 /$ su10061921.

[67] J. Maldonado-Mahauad, M. Pérez-Sanagustín, R. F. Kizilcec, N. Morales, and J. Munoz-Gama, "Mining theory-based patterns from Big data: Identifying selfregulated learning strategies in Massive Open Online Courses," Comput. Human Behav., vol. 80, pp. 179196, 2018, doi: 10.1016/j.chb.2017.11.011.

[68] Y. Lee, "Using Self-Organizing Map and Clustering to Investigate Problem-Solving Patterns in the Massive Open Online Course: An Exploratory Study," J. Educ. Comput. Res., vol. 57, no. 2, pp. 471-490, 2019, doi: 10.1177/0735633117753364. 